\section{Prof. F. A. Lindemann, F.R.S.}

ALL who know Prof. F. A. Lindemann, professor of experimental philosophy in the University of Oxford, will be glad that the King has conferred the honour of a barony on him. Prof. Lindemann is one of the few men of science to rise to a position of influence in affairs in our time and quite possibly the youngest man of science ever to be elevated to the H.ouse of Lords. Those who profess to see in him merely "the man of mystery behind Churchill" or who laud him as the inventor of everything or depreciate him as the thwarter of all good schemes, do injustice to a man of great personality and remarkable parts. At the Prime Minister's right hand he is peculiarly well placed. His foresight, his wide knowledge of the scientific problems that the age and the War have brought forth, his great ingenuity, never more acutely shown than when difficulties are greatest, and his abundant courage, are, perhaps, his most serviceable qualities. There is one other quality, however, of great importance. Prof. Lindemann has a knowledge of the mentality of the French and Germans (he was educated at Darmstadt, Berlin and Paris) which few of the Government advisers could have and more 'realistic' than official advisers or diplomats seem to have had. This Continental experience of his, no less than his scientific insight and personal gifts, should stand him in good stead as a member of the Upper House, and in his present responsible position.

\section{The Right Hon. Winston Churchill, F.R.S.}

A UNIQUE ceremony took place in the Cabinet Room at 10 Downing Street on June 12, when the President of the Royal Society, Sir Henry Dale, admitted the Prime Minister into the fellowship of the Society. Among those present were the Society's biological secretary, Prof. A. V. Hill, M.P., the physical secretary, Prof. A. C. G. Egerton, the foreign secretary, Sir Henry Tizard, and the assistant secretary, Mr. John D. Griffith Davies. After the Prime Minister had signed his name in the ancient Charter Book, Sir Henry Dale showed him the signature of his ancestor, Sir Winston Churchill, father of the great Duke of Marlborough, who was one of the early fellows of the Society, having been admitted into the fellowship in $\mathbf{1 6 6 4 .}$

\section{The Union Observatory, Johannesburg}

The Union Astronomer, Dr. H. E. Wood, director of the Union Observatory, Johannesburg, retired on February 3. Dr. Wood, who was edueated at the University of Manchester, was appointed assistant at the Transvaal Observatory, under the directorship of the late Dr. R. T. A. Innes in 1908. The work of that Observatory had been largely meteorological, of a routine nature, but after the appointment of Dr. Innes as director, the astronomical work was developed, new instrumental equipment was obtained and the Observatory-the name of which was changed to the Union Observatory in 1912-became one of the most important in the southern hemisphere. Dr. Wood succeeded Dr. Innes as Union Astronomer, on the latter's retirement in 1927. He has been particularly interested in the observation of minor planets and comets; he discovered many new minor planets and computed many orbits of minor planets and comets. Dr. Wood has also been an assiduous observer of occul ations of stars by the moon, and the large number of occul ations observed at the Union Observatory for many years has been of the greatest value in the study of the moon's motion. Dr. Wood has been elosely associated with the South African Association for the Advancement of Science, of which he was for many years one of the secretaries and of which he was president in 1931 .

Dr. H. E. Wood has been succeeded as Union Astronomer by Dr. van den Bos, who started his astronomical career as an assistant at the Leyden Observatory. A scheme of co-operation between the Union Observatory and the Leyden Observatory had been arranged, under which the Leyden Observatory -which has a large staff but poor observing conditions-should station one member of its staff at the Union Observatory-which has a small staff but good observing conditions-to whom all necessary facilities should be offered. Under this scheme Dr. van den Bos, whose primary interest is double-star observation, went to Johannesburg in 1926 to make observations of double stars with the large $26 \frac{1}{2}$-in. visual refractor. In 1927 he was transferred to the staff of the Union Observatory, becoming chief assistant in succession to Dr. Wood, on his appointment as Union Astronomer. Dr. van den Bos is not only an assiduous and accurate double-star observer but has also computed many double star orbits. With the collaboration between Dr. van den Bos and Mr. Finsen, one of his assistants, the Union Observatory is now making a more important contribution than any other observatory to double star astronomy. Among interesting observations made by Dr. van den Bos and Mr. Finsen have been the apparent triplicity of Nova Pictoris, a few years after its outburst, the three nuclei showing a progressively increasing separation; also the figure ofeight appearance of the asteroid Eros at the 1931 opposition, which rotated in the period of the variation of brightness of Eros.

\section{U.S. National Academy of Sciences : Recent Elections}

AT the annual meeting of the U.S. National Academy of Sciences, recently held at Washington, the following were elected foreign associates: Prof. E. D. Adrian, professor of physiology in the University of Cambridge; Prof. A. V. Hill, secretary of the Royal Society and Foulerton research professor (Nature, May 10, p. 573); Sir Arthur Keith, formerly Hunterian professor of the Royal College of Surgeons (NATURE, May 24, p. 639).

The following American men of science were elected to membership: Prof. W. E. Bachmann, associate professor of chemistry in the University of Michigan ; Dr. R. J. Dubos, associate in bacteriology in the Rockefeller Institute for Medical Research; Prof. E. A. Graham, professor of medicine in Washington University (St. Louis); Dr. A. S. King, superintendent of the physical laboratory, Mount 
Wilson Observatory ; Prof. C. C. Lauritsen, professor of physics in the California Institute of Technology ; Dr. A. L. Loomis, director of the Loomis Laboratories, Tuxedo Park, N.Y. (physics); Prof. J. R. Oppenheimer, professor of physics in the University of California; Prof. J. T. Patterson, director of zoological research in the University of Texas; Prof. Karl Sax, professor of botany in Harvard Univerisity ; Dr. G. G. Simpson, associate curator of vetebrate palæontology in the American Museum of Natural History ; Dr. Joseph Slepian, Westinghouse Electric and Manufacturing Company (electrical engineering); Dr. L. F. Small, National Institute of Health (organic chemistry); Dr. W. M. Stanley, associatie member in biophysics of the Rockefeller Institute for Medical Research; Prof. T. Y. Thomas, professor of mathematics in the University of California at Ios Angeles; Prof. G. B. Wislocki, Parkman professor of anatomy in Harvard University.

\section{University College, Nottingham: Air-Raid Damage}

NotTINGHam University College buildings in Shakespeare Street have been damaged by a high explosive bomb of heavy calibre. The Departments of Mining and Textiles occupy the Shakespeare Street buildings. The Faculties of Arts and Pure Science and the Departments of Engineering are housed in University Park buildings. The main damage was confined to the west wing of the building, the principal lecture theatres and laboratories, though seriously damaged, escaping destruction. The Mining and Fuels Department was almost completely destroyed, including practically the whole of its valuable apparatus.

In the Textiles Department, which was housed in that section of the building formerly occupied by the Natural History Museum until it was transferred to Wollaton Hall, some of the hosiery machinery was salvaged, but much damage was done to the general structure of that part of the building. Blast broke windows, removed doors and blew down plaster, etc., in practically all parts of the building.

\section{German Aircraft Design}

Technical details now available of the new German fighter, Messerschmitt $109 F$, indicate the general trend of enemy aircraft design towards high altitude operation. The machine, a modification of earlier Messerschmitt fighters, is clearly designed not only to reach great heights, but also to retain climb and general manœuvrability at those altitudes, without which the operation of air fighting is at a tactical disadvantage. It is claimed that this design has a service ceiling of $38,000 \mathrm{ft}$., but the attainment of this height alone has little advantage, it being necessary to retain a speed of manœuvre better than the opposing aircraft, for fighting purposes.

The wing area has been increased, an alteration necessary for this effect, but disadvantageous in many other respects. The amount of armament has been decreased to one cannon and two machine guns. Weight reduction is also an advantage for high altitude work, but a lessening of fire power has obvious drawbacks in a fighter. All guns are now enclosed in the body, the outboard ones on the wings being discarded. The concentration of weight nearer the centre of the machine would improve the quickness of the response to lateral control. Possibly it also reduces the weight and complication of the arrangement for heating the guns, as they would be nearer to the engine, the most convenient source of heat available. It is essential in high altitude flying to prevent freezing up of guns, while they are not in action, by some externally applied heat.

\section{Engineering Economy and Esthetics}

THE Council of the Institution of Civil Engineers has recently given consideration to the need to fost $\mathrm{r}$ among engineers the closer study of : $(a)$ the economics of engineering projects ; $(b)$ the organization and management of engineering work; and $(c)$ the relations of rsthetic considerations to engineering design and construction. It is believed that in the period of reconstruction and development which will follow the War these subjects will become of increasing importance, and in the national interest should form a part of the equipment with which engineers should be furnished in order that they may adequately play their part in the task before them. The Council accordingly intends to examine all possible means by which the Institution can influence the better understanding of engineering economics and rsthetics, not only by students resident at the universities, but also by those otherwise engaged in their engineering training, so that eventually a study of these subjects may form an integral part in the recognized education of all engineers.

As a beginning, the Council of the Institution approached the University of Cambridge with an offer to finance for a period of five years a lectureship on the subjects envisaged in the hope that they would in due course form part of the engineering curriculum of the Mechanical Sciences Tripos. The proposal was cordially welcomed, and has now been accepted in principle by the Council of the Senate of the University; but its full adoption will necessitate some reconsideration of the scheme of instruction in the Engineering School and possibly of the Mechanical Sciences Tripos, which it would be impracticable to undertake in war-time. Nevertheless, during the next academical year, a number of eminent engineers and others will be invited to visit the University to give either single lectures or short courses on subjects coming within the terms of the proposal.

\section{Foreign Periodicals in War-time}

THE Association of Special Libraries and Information Bureaux is undertaking a survey in Great Britain of the present position in regard particularly to enemy and enemy-controlled publications, especially the current issues of periodicals. Previous explanatory surveys have confirmed the impression that since the early part of 1940 only very limited supplies of such publications have been arriving in Great Britain ; that they consist mainly of imperfect sets of a relatively few periodicals restricted very largely to departmental libraries that are not accessible to the general public; and that there is 